\title{
STRATEGIC PRIORITIES FOR THE PROVISION OF AGRICULTURAL ENTERPRISE DEVELOPMENT
}

\author{
Maryna Resler \\ University of Economics and Public Administration Management in \\ Bratislava, Bratislava, Slovakia \\ https://orcid.org/0000-0002-3787-9472
}

\author{
Diana Maksymenko \\ Mukachevo State University, Mukachevo, Ukraine \\ https://orcid.org/0000-0003-2053-8070
}

CMESTE

JELCategory: L30

\begin{abstract}
For agrarian production from possible risks, there is a risk that is related to a reduction of demand on agrarian products from the side of the world agrarian market. Also, world prices on the basic export products of the Ukrainian agrarian enterprises grain-crops diminished considerably, which practically did unprofitable the modern Ukrainian agrarian. Contradictions that arise in the internal and external environment, complicate their activities and reduce their effectiveness. It is difficult for enterprises to adapt to fast and inadequate market requirements. Under such conditions, survive only those enterprises that pay enough attention to strategic analysis, to the choice of directions of activity, to the formation of goals, and to strategic planning. So, strategic management becomes an indispensable tool for the existence of enterprises, and it is the means of achieving equilibrium and finding new factors for competitiveness in the future. Agriculture remains the basis of agrarian production today. The spread of negative trends in agriculture, increased competition, worsening of the social position of commodity producers, and the ineffectiveness of existing methods of managing economic processes require new approaches to improving the efficiency of agribusiness management and the formation of a new type of thinking from managers.
\end{abstract}

Keywords: strategy, agricultural sector, strategic management, diagnostics, strategic goals.

\section{INTRODUCTION}

Dynamic external environment and sharp competition imply a need to develop an effective

Address of the corresponding author: Maryna Resler

玤=marynaresler@gmail.com strategy in agricultural enterprises. However, the strategy is associated with many problems.

On the one hand, strategic management as a branch of scientific research today is characterized by the plurality that acts of conceptual approaches, which explains the lack of unified conceptual and methodological apparatus. 
On the other hand, the strategy of agricultural enterprises due to the specificity of business entities (complex, multi-functional orientation), and increases the uncertainty surrounding the business environment. Timely identification of problems in the field of strategic management in agricultural enterprises helps them to maintain market positions. The correct diagnosis strategy of agricultural enterprises will facilitate the systematization of existing conceptual approaches to the formation of strategy and, therefore, the unification of the conceptual apparatus of strategic management, as well as the development of relevant methods and tools of diagnosis of the agricultural strategy of the enterprise. At the present stage of development of the theory of strategic management is dominated by resource approach to strategy, the main thesis of which is that the competitive advantages of the enterprise caused by the presence in it of unique resources that are a source of economic rent. The unique resources, in turn, determine the uniqueness of the new strategy. The choice of this approach as a conceptual platform makes clear the need to diagnose problems of formation and realization of the strategy of agricultural enterprises based on effective tools. The strategic direction in the theory of enterprise management at the present stage is characterized by the absence of a single conceptual-methodological apparatus, as well as by the plurality of conceptual platforms. The theoretical foundations of the formation of the strategy of the company are laid in the works of many scientists as Ansoff I., Baye M., Porter M., Ivanuch R., Laburtseva O., Higgins J., and many others.

\section{RESEARCH METHOD}

The research methodology is based on the systematic approach and the scientific apparatus of the method of economic analysis, abstractlogical, comparative-historical, monographic, historical-logical, and other methods of conducting analytical research. In particular, the following methods were used in the research process: generalization for the study of the content and nature of the strategic management category; comparative analysis for the evaluation of the activities of agrarian enterprises; expert assessments were used to study the practice of strategic management in agrarian enterprises.

\section{RESEARCH RESULTS}

Agriculture remains the basis of agrarian production today. The spread of negative trends in agriculture, increased competition, worsening of the social position of commodity producers, and the ineffectiveness of existing methods of managing economic processes require new approaches to improving the efficiency of agribusiness management and the formation of a new type of thinking from managers.

Achievement of goals related to ensuring the rational functioning of agrarian organizations requires the development of the strategic management system, positively affects the increase of the efficiency of the agro-industrial complex in general. Management is an objective necessity, which stems from the essence of enterprise strategy and provides for effective achievement of economic methods and means. A timely diagnosis of agricultural enterprises strategy avoids typical strategic management mistakes. The primary objective of the formation of effective methods of diagnosis agricultural enterprise strategy is to define its scope. The advantage of using as the basis of the diagnostics of business processes occurring in the enterprise is their characteristic dynamics, which stipulates the requirement for their continuous improvement. Focusing on the business process allows to better understand the strategic goals and performance of the enterprise (Ansoff, 2006).

An analysis of existing approaches to strategy formation has shown that the development of a modern conceptual platform proceeds from the following prerequisites. First, the revitalization of finding sustainable competitive advantage within the framework of a resource approach that arose in strategic management in the '80s of the twentieth century. At the present stage, the resource approach applied to the strategy of agricultural enterprises offers strategic advantages that define the basic competencies that help to justify the direction of the diagnostic strategy of the agricultural enterprise. Secondly, the effective strategies of agricultural enterprises 
must accumulate in themselves achievements and position of key concepts. During the developing strategies in the agrarian sector, one should consider the specifics characteristic of this sphere of the economy: seasonality, incomplete production in agriculture, cyclical of the animal products; increased riskiness of agricultural production; uneven revenue and the need for lending operating costs; slow capital turnover (Laburtseva, 2014).

The priority objectives of agrarian enterprises within the framework of strategic management are:

1. Strengthening of positions in the agroindustrial complex, including through diversification of production, development of new markets.

2. Improving the overall financial and economic situation, which is achieved not only by increasing production volumes but also a mode of economy, maneuvering of their assets, streamlining financial calculations, and several other actions.

3. The achievement of high business reputation, which requires the implementation of an irreproachable internal organization policy, where among the priorities is the timely performance of contracts, honesty in the calculations, high quality of goods and services.

4. Ensuring high reliability in production and economic activity by creating powerful and resource reserves, insurance reserve funds, developed risk insurance system (Baye M. 1999).

Agriculture is a complex of technologically and organizationally interconnected industries, which in their totality forms a balanced, integrated, and structurally completed system, its functionalcomponent structure is subordinated to a stable increase in agricultural production and livestock production. Each branch of agricultural production is a collection of companies that produce certain similar products or provide services that meet the specific needs of the population in food and industry in raw materials (Ansoff, 2006). Agricultural production includes growing crop production, livestock farming, including cultivation, livestock breeding, and care, gardening, forestry, primary processing of agricultural products by land users, etc. The specificity of the agrarian sector determines the peculiarity of the tasks of management of agricultural production, which, in its turn, presupposes the uniqueness of the principles, functions, and methods of strategic management. Differentiation of agrarian enterprises objectively requires different development strategies, which can only be justified based on identifying and exploring the factors that determine the possibilities for their implementation (Higgins J.M., 1983). The main factors include the degree of economic independence in making strategic decisions, financial status, resource availability, investment attractiveness, the availability of competitive advantages, and the possibility of their implementation. Agricultural enterprises that can be attributed to small-scale land use to small enterprises, as well as large enterprises, have both advantages and disadvantages that will influence the chosen strategy. In farms, at first, high motivation for labor behavior and low production management costs. At the same time, there are problems with the effective use of hightech equipment, there are no conditions for diversification of production (Ivanukh, 2003). All large farms always have problems with providing high labor motivation, high costs of production management. According to the results of the survey of agricultural enterprises in the Transcarpathian region, it was found that strategic management in domestic farms, answering, in general, the basic requirements of production, finally, as the system has not yet developed (Ansoff, 1999).

In the possession and use of agricultural enterprises in Transcarpathia in 2016, there were 404.2 thousand hectares of agricultural land, of which 324.0 thousand hectares of arable land. The share of the population employed in agriculture reached $30 \%$. During this period, there were 1189 agricultural enterprises of different forms of ownership and management operating in the region, which engaged in the production of crop and livestock products (Table 1). The share of gross agricultural production in them for 20122016 years had a steady decline and in 2016 it was $96.8 \%$ of the total volume. 
Resler, M. Strategies of agricultural enterprise development

MEST Journal, Vol. 9 No. 2 pp. 61-67

Table 1 Characteristics of agriculture in the Transcarpathian region *

\begin{tabular}{|l|r|r|r|r|r|r|}
\hline \multicolumn{1}{|c|}{ Indication } & $\mathbf{2 0 1 2}$ & $\mathbf{2 0 1 3}$ & $\mathbf{2 0 1 4}$ & $\mathbf{2 0 1 5}$ & $\mathbf{2 0 1 6}$ & $\begin{array}{r}\mathbf{2 0 1 6} \text { to } \\
\mathbf{2 0 1 2} \text { in\% }\end{array}$ \\
\hline $\begin{array}{l}\text { The number of active } \\
\text { agricultural enterprises }\end{array}$ & 1116 & 1144 & 1173 & 1119 & 1189 & 106.5 \\
\hline $\begin{array}{l}\text { The volumes of sold products } \\
\text { of agriculture, UAH }\end{array}$ & 633,042 & 680,090 & 841,927 & $1,371,747$ & $1,724,768$ & 272.4 \\
\hline $\begin{array}{l}\text { The share of agricultural } \\
\text { production in agricultural } \\
\text { enterprises, in\% of total }\end{array}$ & 104.0 & 102.5 & 99.9 & 95.1 & 96.8 & 93.1 \\
\hline incl. Products & 105.6 & 102.4 & 103.3 & 95.4 & 101.8 & 96.4 \\
\hline The plant growing & 102.5 & 102.6 & 96.5 & 94.7 & 91.5 & 89.3 \\
\hline Animal husbandry & & & & & \\
\hline
\end{tabular}

* Source: according to the data of the Main Directorate of Statistics in the Transcarpathian region

The economic efficiency of agricultural production at Transcarpathian enterprises during 2012-2016 was characterized by stable growth (Table 2), which in turn indicates an increase in the efficiency of the management system in agricultural enterprises. The situation has changed in 2013 when there is a sharp decline in efficiency (a decrease in the profit from sales of agricultural products in comparison with 2012 by $23.4 \%$ ), which is explained by the historical events in Ukraine, which began in November (the period when the harvest was harvested "Went out" to the market or was supplied for processing). However, the situation was equalized in 2014, which was reflected in the growth of profitability compared to 2013.

Table 2 Economic efficiency of production in agricultural enterprises of the Transcarpathian region*

\begin{tabular}{|l|r|r|r|r|r|r|}
\hline \multicolumn{1}{|c|}{ Indication } & \multicolumn{1}{|c|}{$\mathbf{2 0 1 2}$} & $\mathbf{2 0 1 3}$ & $\mathbf{2 0 1 4}$ & $\mathbf{2 0 1 5}$ & $\mathbf{2 0 1 6}$ & $\begin{array}{c}\mathbf{2 0 1 6} \text { to } \\
\mathbf{2 0 1 2} \text { in \% }\end{array}$ \\
\hline $\begin{array}{l}\text { The share of firms that received } \\
\text { net income in the total number } \\
\text { of enterprises, \% }\end{array}$ & 89.1 & 90.0 & 90.1 & 91.2 & 91.8 & 103.0 \\
\hline $\begin{array}{l}\text { Profit, loss (-) from the sale of } \\
\text { agricultural products by } \\
\text { agricultural enterprises, } \\
\text { MM UAH }\end{array}$ & 9.0 & 6.9 & 16.2 & 16.1 & 16.8 & 186.7 \\
\hline $\begin{array}{l}\text { Labor productivity by 1 } \\
\text { employed in agricultural } \\
\text { production, UAH }\end{array}$ & $55,723.6$ & $52,789.3$ & $75,071.0$ & $68,901.0$ & $72,431.1$ & 130.0 \\
\hline $\begin{array}{l}\text { Level of profitability of } \\
\text { agricultural production,\% }\end{array}$ & 6.3 & 4.5 & 7.2 & 30.9 & 26.0 & 412.0 \\
\hline
\end{tabular}

* Source: according to the data of the Main Department of Statistics in the Transcarpathian region

The especially noticeable political situation reflected the efficiency of crop production, such as potatoes and vegetables, production of which has tended to decrease (Table. 3 ). The efficiency of livestock production was characterized by a decrease in meat against the background of egg growth. 
Table 3 Production of basic crops at the enterprises of the Transcarpathian region*

\begin{tabular}{|c|c|c|c|c|c|c|c|}
\hline Indication & 2012 & 2013 & 2014 & 2015 & 2016 & $\begin{array}{c}2016 \text { to } \\
2012 \\
(+,-)\end{array}$ & $\begin{array}{c}2016 \text { to } \\
2015 \\
(+,-)\end{array}$ \\
\hline \multicolumn{8}{|l|}{ Crop production } \\
\hline cereal crops & 3220.5 & 3250.2 & 3433.9 & 3323.7 & 4124.4 & 903.9 & 800.7 \\
\hline sunflower seeds & 64.8 & 97.0 & 60.2 & 46.8 & 68.8 & 4 & 22 \\
\hline potato & 6086.1 & 6148.9 & 6108.6 & 5458.2 & 5342.7 & -743.4 & -115.5 \\
\hline vegetable crops & 2877.2 & 2890.0 & 2970.2 & 2672.5 & 2671.7 & -205.5 & -0.8 \\
\hline fruit crops and berries & 1141.2 & 1184.5 & 1330.7 & 1384.1 & 1285.5 & 144.3 & -98.6 \\
\hline \multicolumn{8}{|l|}{ Animal husbandry } \\
\hline meat, thousand tons & 58.4 & 58.6 & 59.7 & 53.2 & 51.3 & -7.1 & -1.9 \\
\hline milk, thousand tons & 401.1 & 410.3 & 409.6 & 358.1 & 320.4 & -80.7 & -37.7 \\
\hline chicken eggs, million pcs. & 332.6 & 337.5 & 339.3 & 339.9 & 349.4 & 16.8 & 9.5 \\
\hline wool, tons & 213 & 216 & 205 & 185 & 181 & -32 & -4 \\
\hline
\end{tabular}

* Source: according to the data of the Main Department of Statistics in the Transcarpathian region

In practice, an enterprise can simultaneously implement several strategies. But at the same time, the company can predict a certain sequence in the implementation of strategies. In both cases, it is said that the company is implementing a combined strategy. The economic strategy most often used in the work of agrarian enterprises is based on:

- resource concept as an information system that characterizes the aggregate of resources, that is the ability of the enterprise to determine long-term goals and achieve them.

- the theory of competitive advantage as a conceptual basis for the formation of global and local strategic goals of the enterprise and cost-effective means of their achievement.

- the theory of transaction costs as a concept, which allows specifying strategic goals with the greatest efficiency for the enterprise.

The process of determining competitive strategies for agricultural enterprises can be divided into the following consecutive steps:

1. A strategic analysis of the existing situation and identify the key success factors.

2. The development of appropriate indicators for selected key success factors.

3. Development of an adequate information system for providing strategies and reporting on key success factors (Vyatkina T, 2014).
In the conditions of market relations, the only effective management system can provide the enterprises with agro-industrial production, successful businesses, and competitive advantages. Today the company independently determines and predicts the parameters of the environment, the range of products the price proposals, suppliers, markets, etc., and has fast and, most importantly, react to any changes in the external and internal environment and accordingly adjust its activities. While the implementation of strategic management should consider the types of strategies and methodological support of the management process at the level of both businesses and substantiations of the effectiveness of its strategic choice. The need to support the strategic orientation of the company makes the strategic management of the process continuous and dynamic, therefore, one-time analysis and diagnostics cannot be the basis of such a process, because they provide information limited by a specific period.

Strategic management in agrarian enterprises should consider peculiarities of the agro-industrial production, which are in the following. First, product creation in agricultural production is under the influence not only of tools of labor and manpower but also the natural environment. 
Making managerial decisions is an extremely complicated process that occurs in conditions of increased uncertainty and risk. Secondly, the technology of growing agricultural products has a clear sequence of execution of certain stages of work and is complicated. The result of the agroindustrial enterprises depends on timely and strict compliance with the technology. Therefore, management decisions are made within the limits of technological maps. Thirdly, the length of the agricultural production cycle, which can be several years (when planting perennial plantations), affects the duration of their exit from the crisis (more than two years) and the complexity of managing it. Fourth, a significant increase in product volumes can be achieved by intensive technology and efficient operation of the operating system. In this case, an important role should play operational accounting, analysis, and control, which should be carried out by managers at each stage of the technological process. Fifth, the nature of products plays an important role in managing agro-industrial formations. Managers need to identify low-cost production on time, reduce it and at the same time deploy production of highly profitable products and timely diversify its activities. The formation of a strategy for the development of agrarian enterprises should be based on ensuring the competitiveness of agricultural products through the promotion of industry, inter-cooperative associations of commodity producers and raising their level of responsibility for the formation and observance of industry balances, for the quality and safety of products produced by its members, including by creating a collective brand of products introduction of a system of coordination of economic interests in the chain "production-processing-trade"; assistance in the establishment of a system for the joint sale of products of the national agrarian sector on target foreign markets; formation of efficient infrastructure of the agrarian market and ensuring the increased access of producers to organized channels of agricultural products sales, in particular the network of storage and elevator capacities, as well as expansion of opportunities for participation of small forms of management in the organized market; stimulation of rational placement and specialization of agrarian production in accordance with natural climatic conditions (Laburtseva, 2014).

\section{CONCLUSION}

The formation of a strategy for the development of agrarian enterprises should be based on ensuring the competitiveness of agricultural products through the promotion of industry, intercooperative associations of commodity producers and raising their level of responsibility for the formation and observance of industry balances, for the quality and safety of products produced by its members, including by creating a collective brand of products introduction of a system of coordination of economic interests in the chain "production-processing-trade"; assistance in the establishment of a system for the joint sale of products of the national agrarian sector on target foreign markets; formation of efficient infrastructure of the agrarian market and ensuring the increased access of producers to organized channels of agricultural products sales, in particular the network of storage and elevator capacities, as well as expansion of opportunities for participation of small forms of management in the organized market; stimulation of rational placement and specialization of agrarian production in accordance with natural climatic conditions

\section{WORK CITED}

Ansoff, I. (1999). Nova korporatuvna strategiya [New corporate strategy]. Piter, 416p.

Ansoff, I. (2006). Strategichne upravlinnya [Strategic management]. Kiyv : Ekonomika, p.358

Baye, M. (1999). Upravlinska ekonomika i strategiya bisnesu [Management Economics and Business Strategy]. Moscow: Yuniti -Dana, 743p.

Higgins, J.M. (1983). Organizational Policy and Strategic Management: Text and Cases. The Dryden Press, p.3.

Ivanukh, R. A., Dusanovs'kyy S. L., \& Bilan YE. M. (2003). Agrarna ekonomika i rynok [Agrarian economy and market]. Ternopil, $305 \mathrm{p}$. 
Laburtseva, O. (2014). Stratehichna hnuchkist' pidpryyemstva $v$ konteksti orhanizatsiynoho rozvytku [Enterprise strategic flexibility in context of organizational development]. Investytsiyi: praktyka ta dosvid, (4), pp. 29-31.

Porter M.E. (1980). Competitive strategy: techniques for analyzing industries and competitors. New York: FreePress. p. 396

Sait Golovnogo upravlinnya statystyku v Zakarpatskiy oblasti [Site of the Main Department of Statistics in the Transcarpathian Region]. www.uz.ukrstat.gov.ua/ Retrieved from https://www.uz.ukrstat.gov.ua/.

Stratehiya rozvytku ahrarnoho sektoru ekonomiky na period do 2020 roku [Strategy for the development of the agricultural sector of the economy until 2020]. (2017, Oct 17). http://www.uaan.gov.ua Retrieved from https://zakon.rada.gov.ua/laws/show/806-2013-\%D1\%80\#n7.

Vyatkina, T. (2014). Vykorystannya systemnoho pidkhodu do otsinky stratehichnoho upravlinnya resursnym potentsialom pidpryyemstva [The use of a systematic approach to assessing the strategic management of resource potential of the enterprise]. Kiyv: Libra, p. 62-71.

Received for publication: $\quad$ 18.01.2021

Revision received: $\quad 27.02 .2021$

Accepted for publication: $\quad$ 06.07.2021

\section{How to cite this article?}

Style - APA Sixth Edition:

Resler, M., \& Maksymenko, D. (2021, July 15). Strategic priorities for the provision of agricultural enterprise development. (Z. Cekerevac, Ed.) MEST Journal, 9(2), 61-67. doi:10.12709/mest.09.09.02.09

Style - Chicago Sixteenth Edition:

Resler, Maryna, and Diana Maksymenko. 2021. "Strategic priorities for the provision of agricultural enterprise development." Edited by Zoran Cekerevac. MEST Journal (MESTE) 9 (2): 61-67. doi:10.12709/mest.09.09.02.09.

Style - GOST Name Sort:

Resler Maryna and Maksymenko Diana Strategic priorities for the provision of agricultural enterprise development [Journal] // MEST Journal / ed. Cekerevac Zoran. - Belgrade - Toronto : MESTE, July 15, 2021. - 2 : Vol. 9. - pp. 61-67.

Style - Harvard Anglia:

Resler, M. \& Maksymenko, D., 2021. Strategic priorities for the provision of agricultural enterprise development. MEST Journal, 15 July, 9(2), pp. 61-67.

Style - ISO 690 Numerical Reference:

Strategic priorities for the provision of agricultural enterprise development. Resler, Maryna and Maksymenko, Diana. [ed.] Zoran Cekerevac. 2, Belgrade - Toronto : MESTE, July 15, 2021, MEST Journal, Vol. 9, pp. 61-67. 